\title{
The policy of control health and safety and the risk factors in the coal mining of east Kalimantan
}

\author{
Krispinus Duma $^{1 *}$, Adi Heru Husodo², Soebijanto ${ }^{3}$, Lientje Setyawati Maurits ${ }^{4}$ \\ From 7th Postgraduate Forum on Health Systems and Policies \\ Phitsanulok, Thailand. 24-25 June 2013
}

\section{Background}

Occupation within the coal mining company is full of risks. Being located far from residential areas and the risk of occupational health and safety (HS) and the first-hand experience thereof may be considered to be limited to the miners themselves. The control policies by the government issued a once every three months visit to the main site. However, this is regarded as not being effective. Even though the supervision of the company's management during mining process takes place, but there are still a lot of work accidents. The purpose of this research was to design HS module booklet form as a list of assessment of the labour risk factors faced by working in the mines in the works for introspection despite minimal HS control policies.

\section{Materials and methods}

This research employed an analytic quasi-experimental design, non-equivalent control group design approach, which consisted of the treatment group who received the intervention HS module and a control group without intervention. The difference in the output of the two groups was the effectiveness of the intervention module HS. The independent variables investigated were lifestyle, attitude-behaviour-knowledge of HS, and work environment factors with the variables fatigue and accidents. The study population was a heavy equipment operator coal mining company. Purposive sampling with random sampling of 592 operators was undertaken. Multivariate data analysis technique using Structural Equation Modeling with AMOS 7.0 program was employed.

\section{Results}

The lifestyle was negatively correlated with the fatigue variables $(-0.798, \mathrm{p}<0.05)$. Behaviour-attitude-knowledge

\footnotetext{
* Correspondence: pinusei@yahoo.com

${ }^{1}$ Bagian IKM, FK Universitas Mulawarman, Samarinda, Indonesia

Full list of author information is available at the end of the article
}

of HS was negatively correlated with fatigue $(-0.762$, $\mathrm{p}<0.05)$. Work environment factors were positively correlated with fatigue $(0.791, \mathrm{p}<0.05)$. Fatigue was positively correlated with occupational injuries $(0.864$, $\mathrm{p}<0.05)$.

\section{Conclusions}

The present research shows that fatigue was significantly correlated with accidents in coalmines, thus require special attention of HS control policies from policy makers.

\section{Authors' details}

'Bagian IKM, FK Universitas Mulawarman, Samarinda, Indonesia. ${ }^{2}$ Bagian IImu Kesehatan Masyarakat, FK UGM, Yogyakarta 55281, Indonesia. ${ }^{3}$ Bagian Anatomi, FK UGM, Yogyakarta 55281, Indonesia. ${ }^{4}$ Program Studi IImu Kesehatan Kerja, FK UGM, Yogyakarta 55281, Indonesia.

Published: 29 January 2014

doi:10.1186/1471-2458-14-S1-O26

Cite this article as: Duma et al:: The policy of control health and safety and the risk factors in the coal mining of east Kalimantan. BMC Public Health 2014 14(Suppl 1):O26.

Submit your next manuscript to BioMed Central and take full advantage of:

- Convenient online submission

- Thorough peer review

- No space constraints or color figure charges

- Immediate publication on acceptance

- Inclusion in PubMed, CAS, Scopus and Google Scholar

- Research which is freely available for redistribution 